\title{
Pensononowoor
}

2014, vol. 72, 93-102

http://dx.doi.org/10.12657/denbio.072.008

Balázs Garamszegi, Zoltán Kern

\section{Climate influence on radial growth of Fagus sylvatica growing near the edge of its distribution in Bükk Mts., Hungary}

Received: 16 December 2013; Accepted: 11 April 2014

\begin{abstract}
Future of beech (Fagus sylvatica L.) in a changing climate is one of the greatest debates in Europe among the studies dealing with the climate change generated xeric limit shifting. We investigated a submontane beech stand's growth response to climate change in Northern Hungary during the past 60 years following dendrochronological methods. Tree-ring width data were processed using three alternatives of standardization. To recover the basic climate-growth relationships for beech we analyzed the correlation between the tree-ring width indices and monthly precipitation and temperature data, furthermore two drought indices were employed. Late spring-early summer precipitation was the primary climatic factor governing the beech growth at the study site since the early 1950s, while summer heat played a secondary obstructive role documented by the significant negative correlation. A 30-years running window correlation was used to identify whether the climate-growth connections changed due to the unfavorable climatic trends. The results indicated no evidence of a distinct decline in radial increment, however, a significant increase in climatic impact on growth has been detected including probable changes and shifts in the vegetation period.
\end{abstract}

Additional key words: beech, climate change, drought, tree-ring width, vegetation period

Addresses: B. Garamszegi, Department of Meteorology, Eötvös Loránd University, Pázmány Péter sétány 1/c, H-1117 Budapest, Hungary, e-mail: balazs.garamszegi@gmail.com

Z. Kern, Institute for Geological and Geochemical Research, Research Centre for Astronomy and Earth Sciences, MTA, Budaörsi út 45, H-1112 Budapest, Hungary

\section{Introduction}

Forest ecosystems undoubtedly play an important role in the mitigation of the climate change, however, climate change can be a threatening process to them (Bonan 2008; Führer 2010; Gálos et al. 2012). The present and forecasted decline of beech (Fagus sylvatica L.) is one of the greatest debates in the European forestry due to the climate change generated xeric limit shifting. Being one of the most dominant tree species across European forest stands (Fig. 1), a probable mass decline could cause significant ecological changes (maybe ecological catastrophe as well) in the anthropogenically heavily affected forests of the continent (Geßler et al. 2007). The decline has been already shown out at the southern edge of distribution (Jump et al. 2006a; Peñuelas et al. 2007) and the problem is investigated in Central and East Central 
Europe as well (eg. Diaci 2007 in Čufar et al. 2008a; Czúcz et al. 2011; Stojanović et al. 2013). There are very different opinions about the future of the species (van der Maaten 2012). Many studies argued that even radical decrease can be predicted (eg. Geßler et al. 2007; Mátyás et al. 2010; Czúcz et al. 2011; Hlásny et al. 2011; Stojanović et al. 2013), while others suggested more or less adaptation potential (eg. Dittmar et al. 2003; Jump et al. 2006b; van der Maaten 2012; Robson et al. 2013; Tegel et al. 2014). In contrast, some ecological models identified the climate change generated vegetation period shifting as a potential benefit for beech on a longer timescale (Sabaté et al. 2002).

The probable beech decline became a highlighted point of research in Hungary after a mass mortality event in 2004 in southwestern part of the country, likely caused by an accumulated eco-physiological stress due to a couple of dry years (Molnár and Lakatos 2009; Mátyás et al. 2010). Although the beech dominated forests occupy a relatively small area (c. $8 \%$ of total forest coverage) in Hungary, the species plays a significant ecological and economical role besides being also a touristic landscape icon. Considering the ecological respect, the beech forests represent the cool and most humid climate zones in the Hungarian forestry practice besides the further hornbeam-sessile oak, sessile oak-Turkey oak and forest steppe 'climate zones' (eg. Führer et al. 2011).

Although being the 'climate change and fate of beech' topic quite popular, there are very few works that follow dendrochronological methods to investigate the processes and trends of changing beech physiology. However, these methods could be quite useful due to the highly variable tree-ring widths of beech tightly connected to climatic variations (Dittmar et al. 2003; Lebourgeois et al. 2005). In addition the climate influence is increasing on the forest stands approaching their hypothetic xeric limit (eg. Csóka et

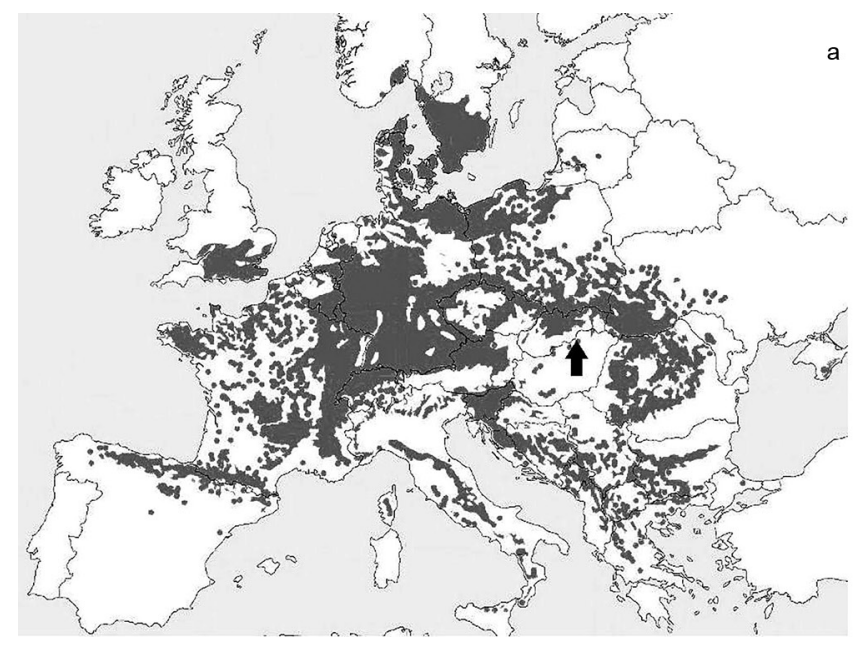

al. 2009; Jump et al. 2010; Mátyás 2010). To contribute to this on-going discussion this study investigated a submontane beech stand's growth response to climate change in Northern Hungary during the past 60 years.

\section{Materials and methods}

\section{Study area and climate data}

The research was carried out in a submontane site of Bükk Mountains, Hungary (N 48 $01^{\prime}$, E 20 21') (Fig. 1). The stand is located on a western slope at an average elevation of $540 \mathrm{~m}$ a.s.l. Although the forest stand is mixed with sessile oak (Quercus petraea (Matt.) Liebl.) and hornbeam (Carpinus betulus L.) the beech is highly dominant, so disturbances from other species on growth are weak. The other species indicate that the stand is situated near to the lower limit of distribution. The soil type is $0.3-0.5 \mathrm{~m}$ deep Cambisol. Due to the soil type, especially its modest water holding capacity and water availability, the area is rather depending on the month by month precipitation. A little ephemeral stream flows in the valley bottom, however it cannot play a significant role in local groundwater recharge. Considering these facts, we expected pronounced climate influence on the trees.

Finding the adequate climate dataset for similar dendroecological studies is usually difficult though, as measurements from farther situated meteorological stations should be used (eg. Čufar et al. 2008a; Jezík et al. 2011; van der Maaten 2012). Here the extended daily E-OBS $0.25^{\circ} \mathrm{x} 0.25^{\circ}$ gridded dataset (Haylock et al. 2008) was used for creating monthly average temperatures and precipitation sums. In 2006 the Hungarian Forest Research Institute has installed automatic climate stations for another research interest 2-3 km far from the area (Manninger 2008), so we could perform a validating and scaling processes with

Fig. 1. Basic site information. Distribution of beech (Fagus sylvatica L.) in Europe (grey shading) (a). The arrow points to the study area (map source : EUFORGEN, 2009). Site photo of a part of the studied forest stand (b) 

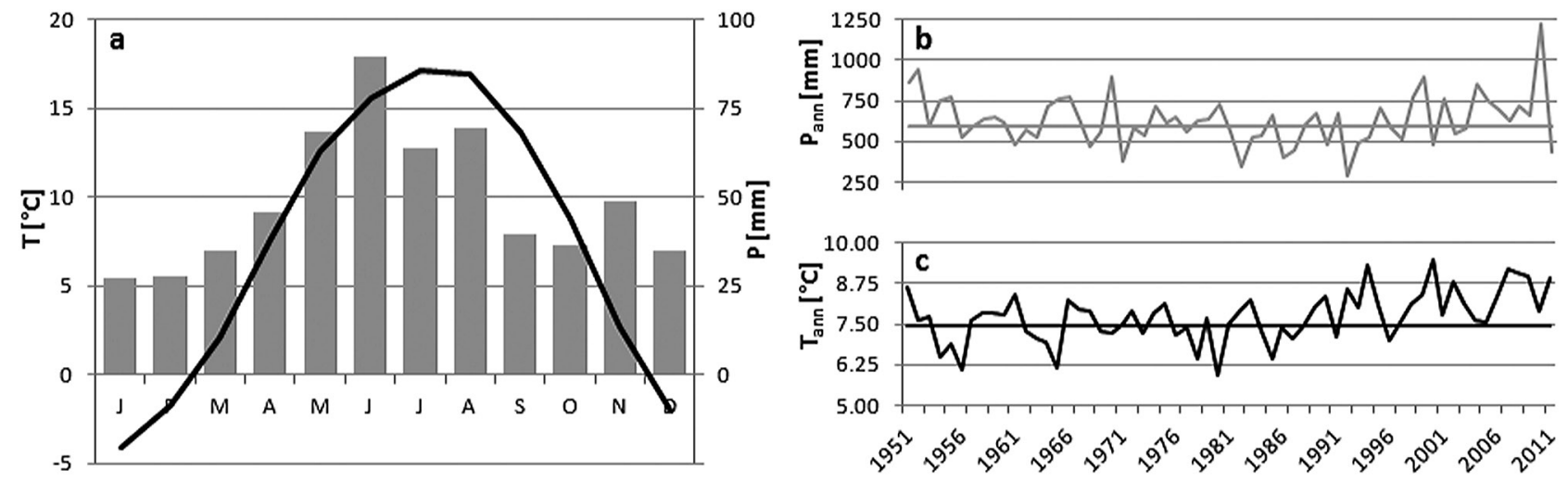

Fig. 2. The climate of the area. Climate diagram (a) shows the average monthly climatic patterns for the 1961-1990 normal period. The long-term variability of annual mean temperature $\left(\mathrm{T}_{\text {ann }}\right)(\mathrm{c})$ and precipitation $\left(\mathrm{P}_{\text {ann }}\right)(\mathrm{b})$ during the study period are also shown. Horizontal lines show the $1961-1990$ averages $\left(7,4^{\circ} \mathrm{C}, 588 \mathrm{~mm}\right)$.

the help of its circa 5 years-long measurements on the E-OBS records spanning from 1951 to 2011. Considering the validation results it can be claimed that the monthly mean temperatures and precipitation sums of the gridded dataset represent the study site at high confidence levels. Some basic climate characteristics of the area are presented in Fig. 2.

Besides using these monthly data, two types of drought indices were computed based on the primary climatological data. The Ellenberg Quotient (EQ) (Ellenberg 1988), that deals with the entire year's precipitation sum and the mean temperature of July, is quite popular in beech and climate change oriented studies. The other one is the Simplified Forest Aridity Index (FAI) (Führer et al. 2011). This latter index combines precipitation and temperature elements of the months of the vegetation season. As far these two indices are widely used in case of many similar researches, we used them basically to make our results comparable with others' works.

\section{Tree sampling and measurement of the radial increments}

Eight disk samples were collected from freshly exploited logs in autumn and early winter 2012 . Samples were processed following standard dendrochronological protocol (Stokes and Smiley 1968; Popa 2004). Disks were sanded and polished to enhance the visibility of ringwidth structure. Ring width measurements were made with a resolution of $0.01 \mathrm{~mm}$ along two radii per each disk using a LINTAB measuring table and TSAP-Win 4.67 software (Rinn 2005). Due to the frequent irregularities and scars one disk was excluded from further analysis. Ringwidth series were synchronized first by visual comparison (Stokes and Smiley 1968) and finally measurement errors and missing rings were checked by COFECHA (Holmes 1983). Measurement and crossdating was done using the facilities of the Budapest Tree-Ring Laboratory (Eötvös Loránd University, Dept. of Palaeontology) (Kázmér and Grynaeus 2003). The final chronology spans from 1947 to 2011.

\section{Standardization of tree ring data}

A mandatory step preceding evaluation of growth-climate relationship is standardization (Cook et al. 1990) in order to remove age related trends and growth disturbances due to forest dynamics. However, there are many alternative standardization techniques and every technique has some advantages and disadvantages as well. In order to partially eliminate potential biases of any particular standardization technique, raw tree-ring width (TRW) data have been processed following three different routes and each variant was involved into the further growth-climate evaluation step. Alternative standardizations were (Fig. 3):

i) 30-yr cubic smoothing spline (spl30) fitting to individual series (Cook and Peters 1981). This is a quite flexible model. Expectedly interannual-subdecadal variations can be captured following this approach.

ii) Hugershoff function (Hug) is an alternative approach when a polynomial-exponential combined function is fitted to the measured data and fitting parameters iteratively tuned (Warren 1980). This is a classical standardization technique frequently applied in climate-growth studies and quite popular in forestry science.

iii) 'signal free' standardization (sigF). The classical data-adaptive techniques could be biased because the fitted curves may incorporate the climate signal, which is termed as 'trend distortion' problem (Melvin and Briffa 2008). In this approach each measurement series was detrended with a smoothing spline (Cook and Peters 1981) with a $50 \%$ frequency cut-off at two-thirds of the series 

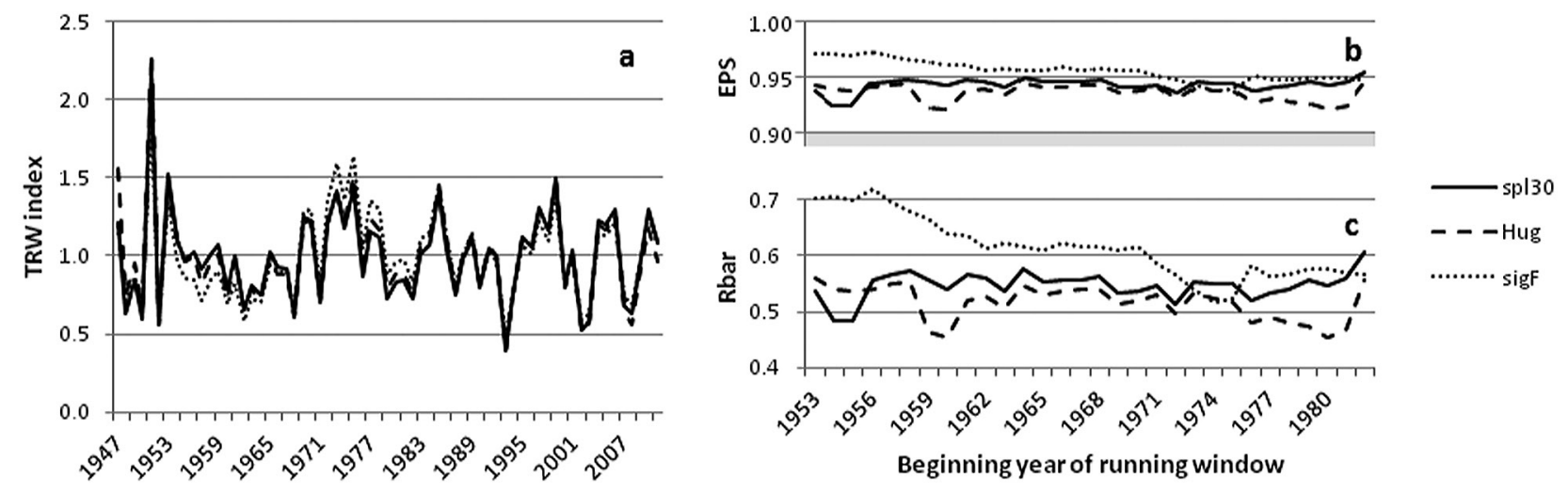

Fig. 3. TRW indices (a) for the period between 1947 and 2011 after each detrending method. EPS (b) and Rbar (c) values using each detrending method with $30 \mathrm{yrs}$ (in case of sigF 31 yrs) running windows from 1953

length. Convergence test was set to 0.0005 , minimizing the mean absolute difference between the current and the preceding chronologies, and the limit has been reached at the 12th iterative step. Signal-free methods can improve the resolution of medium-frequency variance (Melvin and Briffa 2008).

Standardization and index calculation procedure was carried out using the ARSTAN software (Cook and Krusic 2006) for i) and ii) while the RCSsigFree software (Melvin and Briffa 2014) was used for iii). Individual indices were derived as ratio between raw measurement and the modeled growth. Regarding the characteristically modest autocorrelation of beech (van der Werf et al. 2007), standard version of the produced TRW chronologies have been used. Variance adjustment adopting the running window correlation approach (Frank et al. 2007) was applied on the derived chronologies to minimize variance bias (Osborn et al. 1997) due to changing sample replication and the effect of fluctuating interseries correlation. Mean chronology was calculated as biweight robust mean following each standardization variants. Signal strength in the index series was controlled by the Expressed Population Signal (EPS) statistics (Wigley et al. 1984). EPS estimates how well a finite number of analyzed samples represent the theoretical stand average. Although traditionally 0.85 is adopted as a critical level, a recent evaluation recommended higher level (approx. 0.90) for chronology acceptance (Mérian et al. 2013). The more rigorous recommendation was adopted in this study. Mean interseries correlation (Rbar) and EPS were calculated with 30 yrs (in case of sigF 31 yrs) running windows (Fig. 3).

\section{Results}

\section{Tree-ring index variants}

Derived index series and the signal strength statistics are shown in Fig. 3. As only one sample disc was dated back before 1953, the discussion will be restricted only to the latter period and the EPS and Rbar statistics are shown in Fig. 3 beginning with 1953 therefore. Hug and spl30 tracks very closely each other, while sigF chronology deviates a bit from them. SigF shows higher values for the late 1970s and lower values over the 1953-63 decade.

Regarding the interseries correlation (Rbar) Hug seems to preserve the weakest coherence and usually sigF showed the best performance. Running values of EPS are above the traditional signal acceptance level, however sigF fluctuates around, or frequently above the 0.95 level. Taking all together, signal strength statistics suggests that despite the relatively modest replication the chronology carries a very robust signal which is practically representative for the studied stand. In addition, sigF seems to preserve the strongest common signal among the three tested standardization alternatives for the studied beech samples.

\section{Investigating general climate-growth relationship}

To recover the basic climate-growth relationships we analyzed the correlation between the TRW indices and monthly precipitation and temperature data. Following dendroclimatogical practice to recover the importance of the previous year's climate on the growth (eg. Di Filippo et al. 2007; Kern and Popa 2007; Tegel et al. 2014), correlation analysis comparing annual variations of radial growth of beech with the monthly climate variability were performed from previous May to October of the current year. Using different standardization methods were recommended to avoid any bias due to the probable similar direction of trends both for growth and changing climate. It was found that the signal-free iterations play a more effective role in recovering the medium-frequency growth deviations than the traditional methods (Fang et al. 2012). However, as can be seen in Fig. 4, the other 
two methods met higher correlations with the climate data.

It is clearly visible that water availability is the main determinative meteorological element regulating beech growth at the studied site similarly to many previous findings (eg. Ellenberg 1988; Geßler et al. 2007; van der Werf et al. 2007), but the higher summer temperatures can have also significant negative impact on radial growth at more xeric sites of distribution (eg. Čufar et al. 2008b). Naturally the summer heat partly also influences through the evaporation impact on water availability and drought conditions. With precipitation data the spl30 indices, while with the temperature averages the Hug approximation provided the strongest correlations. Also the sigF indices showed a more significant relationship with temperature data. Groups of months with the most significant growth relationship for each meteorological elements were identified out of combining the months with higher correlation (though not necessarily above $\mathrm{p}<0.05$ significance level) (Fig. 4). Regarding precipitation the April-May-June sum seemed to be the most appropriate grouping $\left(\mathrm{P}_{\mathrm{AMI}}\right)$. (Late) May and June are obviously the main growing period (eg. Lebourgeois et al. 2005; van der Werf et al. 2007; Cufar et al. 2008a; Prislan et al. 2013) for beech in Central Europe so its moisture regime was expected to be an important factor. The outstanding role of April is much more interesting and discussed in detail later. With temperature data the correlations were fairly lower. The most significant grouping was May-June average temperature $\left(T_{M J}\right)$, representing the main growing months again. Although not being part of the significant group, the limiting role of $\mathrm{Au}$ gust temperature is clear and has been already observed elsewhere (eg. Čufar et al. 2008a; Führer et al. 2011). It is also notable that the present correlations show an extremely low importance of July's weather. The drought indices characterized the annual growth at a less spectacular levels then $\mathrm{P}_{\mathrm{AMI}}$. Nevertheless, being dominated of precipitation elements it is not a surprise that they also show the stronger relation with spl30. The obtained correlations with drought indices were the following: with EQ: -0.331 (spl30), -0.312 (Hug), -0.269 (sigF); with FAI: -0.463 (spl30), -0.415 (Hug), -0.354 (sigF).

\section{Xeric limits for beech and the climate change}

Several studies tried to define climatic limits for beech distribution, which generally means defining a xeric limit as the likely most actual threshold shifting due to the climate change. These theoretical xeric limits are widely used for forecasting the future distribution of beech dominated forests in Southern and Central Europe (eg. Czúcz et al. 2011, Stojanović et al. 2013); therefore we also employed some of those definitions to characterize the changing climatic conditions. As far drought indices are containing information both about precipitation and temperature, they seem to be the best solution for defining xeric limit with only one number, if it is possible at all. Following earlier evaluations EQ $<29$ (Ellenberg 1988; Fang and Lechowicz 2006) and FAI $<4.75$ (Führer et al. 2011) were considered as an upper limit for beech-favored climatic conditions. The EQ and FAI values fluctuated around the limits for the entire 1951-2011 periods so 30 yrs moving averages were calculated to indicate a smoothed trend of climate (Fig. 5). Making averages is also useful considering the fact that shorter periods of drought years do not affect dramatically the physiology of beech (van der Werf et al. 2007; Fotelli et al. 2009; Jezík et al. 2011).

Both indices were stepping over the limit after the first 30 yrs average. This process clearly shows the near-to-the-edge location of the stand, however, it must be mentioned that the trends of averages are obviously influenced by the early 1990s' low precipitation years (eg. Pálfai 2009). As for the future the uptrend is likely to go on. Indices were calculated for

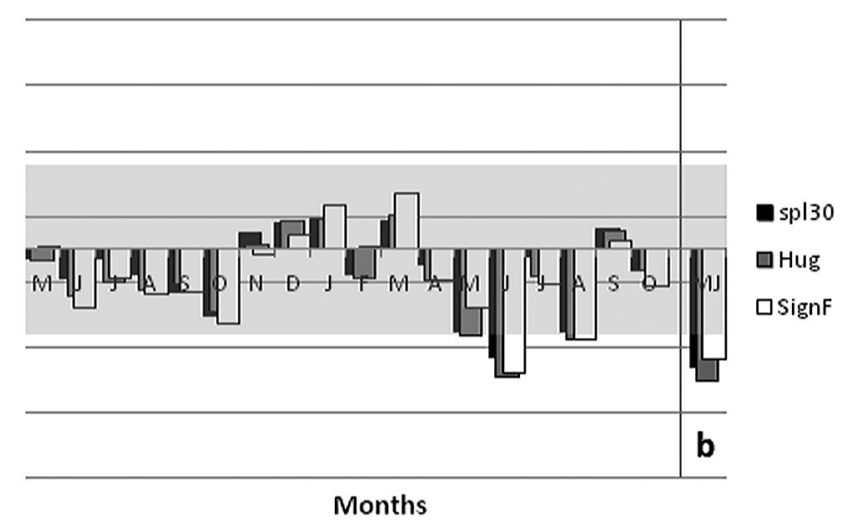

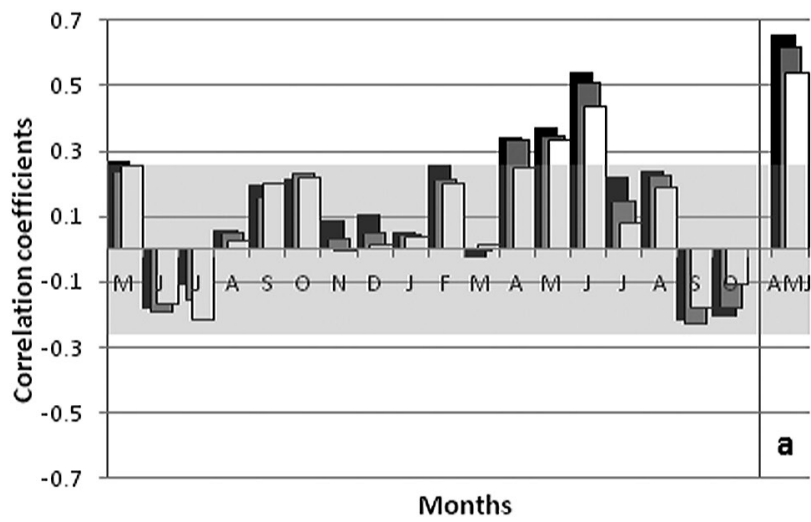

Fig. 4. Growth-climate correlation coefficients of Pearson correlation with monthly precipitation sum (a) monthly average temperature (b) including the most significant groups of months. Outside the grey area $\mathrm{p}<0.05$ significance level 

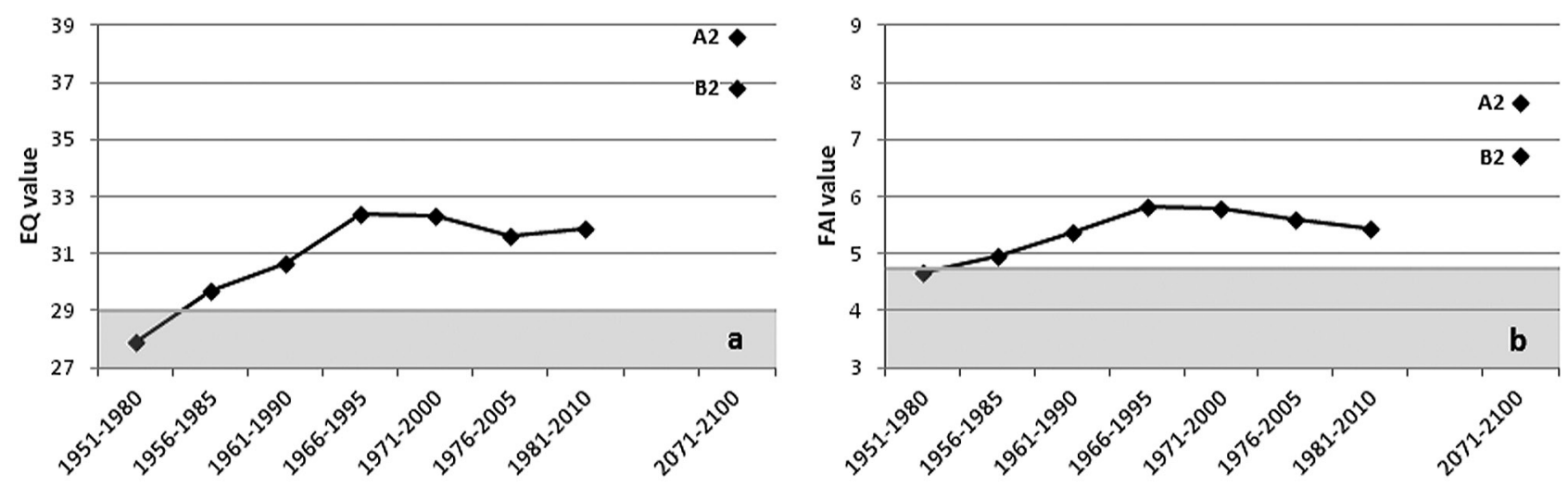

Fig. 5. Changes of 30 yrs averages of EQ (Ellenberg Quotient, Ellenberg 1988) (a) and FAI (simplified Forest Aridity Index, Führer et al. 2011) (b) aridity indices during the study period and projections for 2071-2100 in case of A2 and B2 global emission scenarios (IPCC 2000) induced climate change. Grey area represents the beech-favored province.
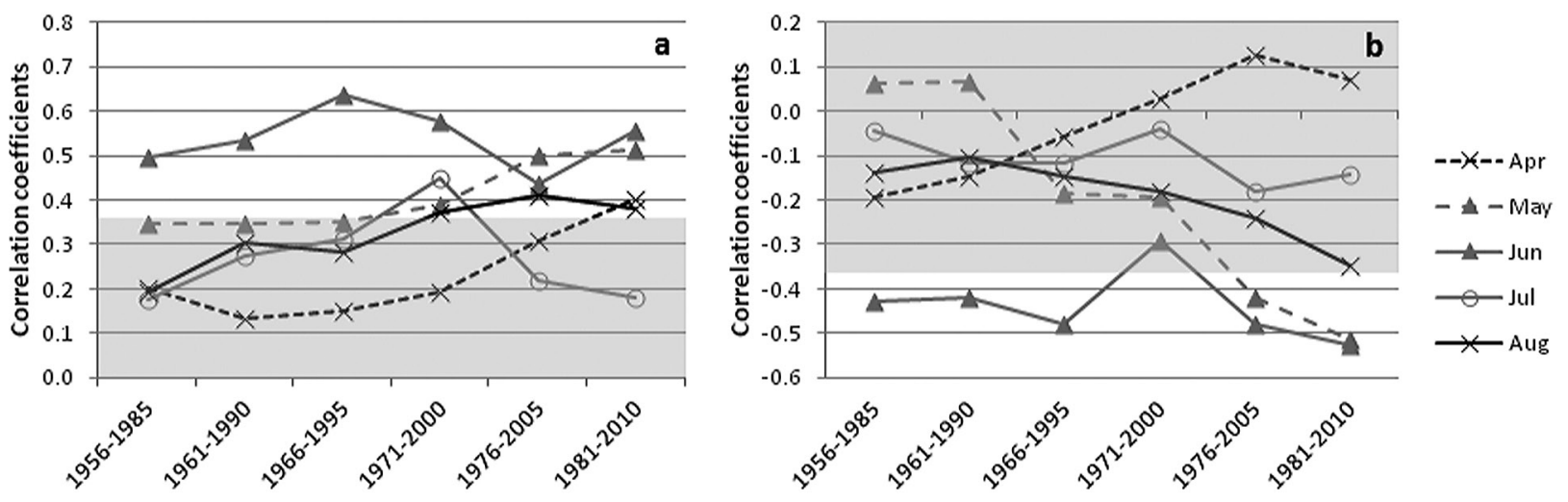

Fig. 6. Moving window correlations for precipitation (a) and mean temperature (b). Outside the grey area $p<0.05$ significance level.

2071-2100 using seasonal projections for the corresponding climate parameters obtained using different scenarios (Fig. 5), though the high variability of projections is clear (for EQ: $\pm 12.5-14.5$; for FAI: $\pm 2.5-$ 3.5 ) due to the propagation of uncertainty (Bartholy et al. 2007; Christensen et al. 2007; Bartholy and Pongrácz 2010).

\section{Changing climate-growth relationship}

Unfavorable climatic trends raise the question whether the climate-growth relationships were changing during the study period as well. For that purpose a 30 yrs moving window correlation analysis with 5 yrs steps was also employed to track any potential shifts in the climate-growth correlation and to find out the ecophysiological tendencies of the stand. Similar kind of investigations have been already performed on subalpine and Mediterranean beech stands, though on a quite different timescale with different purposes and results (Di Filippo et al. 2007; Tegel et al. 2014). The 30 yrs length for each window was recommended to gain significant correlation value for each investigated month, period and meteorological element. The selected months under this process were those of highest correlations and July to cover the whole late spring-summer growing season. Sp130 TRW indices were correlated with precipitation, while Hug approximation with temperature. The results of the analysis can be seen in Fig. 6 .

Changes of relationships partly follow the trends of drought indices. The most dominant month in case of both precipitation and temperature was June, but there is also observed a strengthening of influence of May conditions. Over the last 30 yrs period it has gradually reached the same importance as June. Role of July steadily stayed below the required significance level. Precipitation of April and August and average

Table 1. Correlation coefficients with groups of months and drought indices and their level of significance in each half of the study period. $\mathrm{T}_{\mathrm{MJ}}$ is correlated with Hug, the rest with spl30

\begin{tabular}{lcr}
\hline & $1953-1981$ & $1982-2010$ \\
\hline $\mathrm{P}_{\text {AMJ }}$ & $0.572(\mathrm{p}<0.01)$ & $0.710(\mathrm{p}<0.01)$ \\
$\mathrm{T}_{\text {MJ }}$ & $-0.123(\mathrm{p}>0.1)$ & $-0.617(\mathrm{p}<0.01)$ \\
EQ & $-0.141(\mathrm{p}>0.1)$ & $-0.457(\mathrm{p}<0.05)$ \\
FAI & $-0.483(\mathrm{p}<0.01)$ & $-0.479(\mathrm{p}<0.01)$ \\
\hline
\end{tabular}


temperature of August also showed a growing impact on TRW. The significant groups of months and the correlation with the drought indices themselves have mostly undergone considerable increase in level of significance as well, particularly the $\mathrm{T}_{\mathrm{MJ}}$ (Table 1 ).

\section{Discussion and conclusion}

The found relationships and trends in beech growing on marginal areas are widely comparable with results of other studies dealing with beech ecology. We could follow the changes in a generally undisturbed beech stand during the last 50-60 years. The climatic conditions and principally their trends were rather unfavorable for beech growth during this period, however, no evidence of a distinct decay in growth could be observed by the tested detrending methods. Probably due to the more xeric conditions, a significant increase in climate impact on growth has been detected as also described by several other studies (Csóka et al. 2009; Jump et al. 2010; Mátyás et al. 2010). The projected enhancement in aridity will surely be a major challenge also to the natural regeneration of beech forests (Bílek et al. 2014).

The running window correlation analysis revealed that strengthening climate impact was not uniform for the considered months and climate elements. These tendencies probably indicate some direction of changes and shifts in the vegetation season (eg. Čufar et al. 2012). Strengthening correlations between TRW index and April/May precipitation most probably represent the earlier beginning of the growth season. There is a possibility that vegetation period shifting also means the appearance of a second, less remarkable growing peak after midsummer (July) slowdown (van der Werf et al. 2007; Jezík et al. 2011). In case of certain months, such as May and August, those only recently gained more importance regulating annual growth, we can also count with increased temperature limitation. While these variability around growing season are recognized in space of distribution over long timescales (Di Filippo et al. 2007; van der Werf et al. 2007; Jezík et al. 2011; Tegel et al. 2014) the main point in present study is the fact that remarkable changes can happen even in a lifetime of a tree generation and a small area of a certain forest stand. This may be considered as a short-term response to more xeric conditions.

The differentiating role of growing months also raises the question whether the drought indices are useful for accurate forecast of future xeric limits. Drought indices are undoubtedly good indicators of the short-term hydroclimatological conditions with efficient applications in agricultural meteorology including forestry meteorology (Dunkel 2009). It is difficult though, to find the appropriate weight on cli- mate elements of each month included in a drought quotient (Führer et al. 2011). Use of inflexible indices and xeric limits connected to them may lead to uncertainty around projections of future beech distribution. Although it is difficult to predict the future of the investigated beech stand, it is very likely that due to the recent and projected direction of climate change, the climatic conditions will even more significantly affect the annual growth of trees and possibility of beech decline in the studied region cannot be excluded as well.

\section{Acknowledgements}

Thanks to Hungarian Forest Research Institute and its kind researchers for the climate data and their profitable advices. Thanks to State Forestry Office Eger for the disk samples. We acknowledge the E-OBS dataset from the EU-FP6 project ENSEMBLES and the data providers in the ECA\&D project. Special thanks to Dr. István Matyasovszky from Dept. of Meteorology, Eötvös Loránd University for his help in the statistical analysis of the climate data. Thanks for support from 'Lendület' program of the Hungarian Academy of Sciences (LP2012-27/2012). This is contribution No.09. of '2ka Palæoclimatology' Research Group and No.24. of Budapest Tree-Ring Laboratory.

\section{References}

Bartholy J., Pongrácz R., Gelybó G. 2007. Regional climate change expected in Hungary for 2071-2100. Applied ecology and environmental research 5: 1-17.

Bartholy J., Pongrácz R. 2010. Climate change scenarios for the Carpathian Basin. In: Climate change and Hungary: Mitigation the hazard and preparing for the impacts. The 'VAHAVA' Report. Faragó T., Láng I., Csete L. (eds.). Budapest, pp. 12-21.

Bílek L., Remeš J., Podrázský V., Rozenbergar D., Diaci J., Zahradník D. 2014. Gap regeneration in near-natural European beech forest stands in Central Bohemia - the role of heterogeneity and micro-habitat factors. Dendrobiology 71: 59-71

Bonan G.B. 2008. Forests and Climate Change: Forcings, Feedbacks, and the Climate Benefits of Forests. Science 320: 1444-1449. http://dx.doi. org/10.1126/science.1155121

Christensen J.H., Hewitson B., Busuioc A., Chen A., Gao X., Held I., Jones R., Kolli R.K., Kwon W-T., Laprise R., Magaña Rueda V., Mearns L., Menéndez C.G., Räisänen J., Rinke A., Sarr A., Whetton P. 2007. Regional Climate Projections. In: Climate Change 2007: The Physical Science Basis. Contribution of Working Group I to the Fourth Assessment Report of the Intergovernmental Panel 
on Climate Change. Solomon S., Qin D., Manning M., Chen Z., Marquis M., Averyt K.B., Tignor M., Miller H.L. (eds.). Cambridge University Press, pp. 847-940.

Cook E.R., Peters K. 1981. The smoothing spline: a new approach to standardizing forest interior treering width series for dendroclimatic studies. TreeRing Bulletin 41: 45-53.

Cook E.R., Briffa K., Shiyatov S., Mazepa V. 1990. Tree-ring standardization and growth-trend estimation. In.: Cook, E., Kairiukstis L. (eds.). Methods of Dendrochronology. Applications in the Environmental Sciences, Kluwer Academic Pub, pp. 104-162. http://dx.doi.org/10.1007/978-94-0157879-0

Cook E.R., Krusic P.J. 2006. ARSTAN4.1b_XP. http:// www.ldeo.columbia.edu

Csóka G., Koltay A., Hirka A., Janik G. 2009. Az aszályosság hatása kocsánytalan tölgyesek és bükkösök egészségi állapotára. 'Klíma-21' Füzetek 57: 64-73.

Čufar K., Prislan P., de Luis M., Gricar J. 2008a. Treering variation, wood formation and phenology of beech (Fagus sylvatica) from a representative site in Slovenia, SE Central Europe. Trees 22: 749-758. http://dx.doi.org/10.1007/s00468-008-0235-6

Čufar K., de Luis M., Berdajs E., Prislan P. 2008b. Main patterns of variability in beech tree-ring chronologies from different sites in Slovenia and their relation to climate. Zbornik gozdarstva in lesarstva 87: 123-134.

Čufar K., de Luis M., Saz M.A., Črepinšek Z., Kajfež-Bogataj K. 2012. Temporal shifts in leaf phenology of beech (Fagus sylvatica) depend on elevation. Trees 26: 1091-1100. http://dx.doi. org/10.1007/s00468-012-0686-7

Czúcz B., Gálhidy L., Mátyás C. 2011. Present and forecasted xeric climatic limits of beech and sessile oak distribution at low altitudes in Central Europe. Annals of Forest Science 68: 99-108. http://dx.doi.org/10.1007/s13595-011-0011-4

Di Filippo A., Biondi F., Čufar K., de Luis M., Grabner M., Maugeri M., Saba E.P., Schirone B., Piovesan G. 2007. Bioclimatology of beech (Fagus sylvatica L.) in the Eastern Alps: spatial and altitudinal climatic signals identified through a tree-ring network. Journal of Biogeography 34: 1873-1892. http:// dx.doi.org/10.1111/j.1365-2699.2007.01747.x

Dittmar C., Zech W., Elling W. 2003. Growth variations of Common beech (Fagus sylvatica L.) under different climatic and environmental conditions in Europe - a dendroecological study. Forest Ecology and Management 173: 63-78. http://dx.doi. org/10.1016/S0378-1127(01)00816-7

Dunkel Z. 2009. Brief surveying and discussing of drought indices used in agricultural meteorology. Időjárás 113: 23-37.
Ellenberg H. 1988. Vegetation ecology of Central Europe. 4th ed. Cambridge University Press.

Fang J., Lechowicz M.J. 2006. Climatic limits for the present distribution of beech (Fagus L.) species in the world. Journal of Biogeography 33: 1804-1819. http://dx.doi.org/10.1111/j.13652699.2006.01533.x

Fang K., Gou X., Chen F., Liu C., Davi N., Li J., Zhao Z., Li Y. 2012. Tree-ring based reconstruction of drought variability (1615-2009) in the Kongtong Mountain area, northern China. Global and Planetary Change 80: 190-197. http://dx.doi. org/10.1016/j.gloplacha.2011.10.009

Fotelli M.N., Nahm M., Radoglou K., Rennenberg H., Halyvopoulos G., Matzarakis A. 2009. Seasonal and interannual ecophysiological responses of beech (Fagus sylvatica) at its south-eastern distribution limit in Europe. Forest Ecology and Management 257: 1157-1164. http://dx.doi. org/10.1016/j.foreco.2008.11.026

Frank D., Esper J., Cook E.R. 2007. Adjustment for proxy number and coherence in a largescale temperature reconstruction. Geophysical Research Letters 34: L16709. http://dx.doi. org/10.1029/2007GL030571

Führer E. 2010. Forestry and climate change. In: Climate change and Hungary: mitigating the hazard and preparing for the impacts. The 'VAHAVA' Report. Faragó T., Láng I., Csete L. (eds.). Budapest, pp. 50-54.

Führer E., Horváth L., Jagodics A., Machon A., Szabados I. 2011. Application of a new aridity index in Hungarian forestry practice. Időjárás 115: 205-216.

Gálos B., Hänsler A., Kindermann G., Rechid D., Sieck K., Jacob D. 2012. The role of forests in mitigating climate change - a case study for Europe. Acta Silvicata et Lignaria Hungarica 8: 87-102.

Geßler A., Keitel C., Kreuzwieser J., Matyssek R., Seiler W., Rennenberg H. 2007. Potential risks for European beech (Fagus sylvatica L.) in a changing climate. Trees 21: 1-11. http://dx.doi.org/10.1007/ s00468-006-0107-x

Hlásny T., Barcza Z., Fabrika M., Balázs B., Churkina G., Pajtík J., Sedmák R., Turčáni M. 2011. Climate change impacts on growth and carbon balance of forests in Central Europe. Climate Research 47: 219-236. http://dx.doi.org/10.3354/cr01024

Haylock M.R., Hofstra N., Klein Tank A.M.G., Klok E.J., Jones P.D., New M. 2008. A European daily high-resolution gridded data set of surface temperature and precipitation for 1950-2006. Journal of Geophysical Research 113.

Holmes R.L. 1983. Computer-assisted quality control in tree-ring dating and measurement. Tree-ring Bulletin 43: 69-75. 
IPCC 2000. Special Report on Emissions Scenarios. A special report of Working Group III of the Intergovernmental Panel on Climate Change. Nakićenović N., Swart R. (eds.). Cambridge University Press.

Jezík M., Blazenec M., Strelcová K., Ditmarová L. 2011. The impact of the 2003-2008 weather variability on intra-annual stem diameter changes of beech trees at a submontane site in central Slovakia. Dendrochronologia 29: 227-235. http://dx. doi.org/10.1016/j.dendro.2011.01.009

Jump A.S., Hunt J.M., Peñuelas J. 2006a. Rapid climate change-related growth decline at the southern range edge of Fagus sylvatica. Global Change $\mathrm{Bi}-$ ology 12: 2163-2174. http://dx.doi.org/10.1111/ j.1365-2486.2006.01250.x

Jump A.S., Hunt J.M., Martínez-Izquierdo J.A., Peñuelas J. 2006b. Natural selection and climate change: temperature-linked spatial and temporal trends in gene frequency in Fagus sylvatica. Molecular Ecology 15: 3469-3480. http://dx.doi.org/10.1111/ j.1365-294X.2006.03027.x

Jump A.S., Cavin L., Hunter P.D. 2010. Monitoring and managing responses to climate change at the retreating range edge of forest trees. Journal of Environmental Monitoring 12: 1791-1798. http://dx.doi.org/10.1039/b923773a

Kázmér M., Grynaeus A. 2003. The Budapest TreeRing Laboratory. Association for Tree-Ring Research, Newsletter 1: 5-6.

Kern Z., Popa I. 2007. Climate-growth relationship of tree species from a mixed stand of Apuseni Mts., Romania. Dendrochronologia 24: 109-115. http://dx.doi.org/10.1016/j.dendro.2006.10.006

Lebourgeois F., Bréda N., Ulrich E., Granier A. 2005. Climate-tree-growth relationships of European beech (Fagus sylvatica L.) in the French Permanent Plot Network (RENECOFOR). Trees 19: 385-401. http://dx.doi.org/10.1007/s00468-004-0397-9

van der Maaten E. 2012. Climate sensitivity of radial growth in European beech (Fagus sylvatica L.) at different aspects in southwestern Germany. Trees 26: 777-788. http://dx.doi.org/10.1007/s00468011-0645-8

Manninger M. 2008. Meteorológiai mérések a Bükkben. In: 'Erdészeti beavatkozások fejlesztése az éghajlatváltozás káros hatásainak csökkentése érdekében, a természeti értékek megtartása mellett' címú GVOP project. Részletes szakmai beszámoló, Budapest. pp. 64-75.

Mátyás C. 2010. Forecasts needed for retreating forests (Opinion). Nature 464: 1271. http://dx.doi. org/10.1038/4641271a

Mátyás C., Berki I., Czúcz B., Gálos B., Móricz N., Rasztovits E. 2010. Future of Beech in Southeast Europe from the Perspective of Evolutionary
Ecology. Acta Silvicata et Lignaria Hungarica 6: 91-110.

Melvin T.M., Briffa K.R. 2008. A ‘signal-free’ approach to dendroclimatic standardisation. Dendrochronologia 26: 71-86. http://dx.doi.org/10.1016/j.dendro.2007.12.001

Melvin T.M., Briffa K.R. 2014. CRUST: software for the implementation of Regional Chronology Standardisation: part 1. Signal-free RCS. Dendrochronologia 32: 7-20. http://dx.doi.org/10.1016/j.dendro.2013.06.002

Mérian P., Pierrat J.-C., Lebourgeois F. 2013. Effect of sampling effort on the regional chronology statistics and climate-growth relationships estimation. Dendrochronologia 31: 58-67. http://dx.doi. org/10.1016/j.dendro.2012.07.001

Molnár M., Lakatos F. 2009. Bükkpusztulás Zala megyében. 'Klíma-21' Füzetek 57: 74-82.

Osborn T.J., Briffa K.R., Jones P.D. 1997. Adjusting variance for sample-size in tree-ring chronologies and other regional-mean time-series. Dendrochronologia 15: 89-99.

Pálfai I. 2009. Aszályos évek a Kárpát-medencében a 18-20. században. 'Klíma-21' Füzetek 57: 107112.

Peñuelas J., Ogaya R., Boada M., Jump A.S. 2007. Migration, invasion and decline: changes in recruitment and forest structure in a warming-linked shift of European beech forest in Catalonia (NE Spain). Ecography 30: 829-837. http://dx.doi. org/10.1111/j.2007.0906-7590.05247.x

Popa I. 2004. Fundamente metodologice şi aplicaţii de dendrocronologie. Editura Tehnică silvică, Stațiunea experimentală de cultura molidului.

Prislan P., Gričar J., de Luis M., Smith K.T., Čufar K. 2013. Phenological variation in xylem and phloem formation in Fagus sylvatica from two contrasting sites. Agricultural and Forest Meteorology 180: 142-151. http://dx.doi.org/10.1016/j.agrformet.2013.06.001

Rinn F. 2005. TSAP reference manual.

Robson T.M., Rasztovits E., Aphalo P.J., Alia R., Aranda I. 2013. Flushing phenology and fitness of European beech (Fagus sylvatica L.) provenances from a trial in La Rioja, Spain, segregate according to their climate of origin. Agricultural and Forest Meteorology 180: 76-85. http://dx.doi. org/10.1016/j.agrformet.2013.05.008

Sabaté S., Gracia C.A., Sánchez A. 2002. Likely effects of climate change on growth of Quercus ilex, Pinus halepensis, Pinus pinaster, Pinus sylvestris and Fagus sylvatica forests in the Mediterranean region. Forest Ecology and Management 162: 23-37. http:// dx.doi.org/10.1016/S0378-1127(02)00048-8

Stojanovíć D.B., Kržič A., Matovíc B., Orlovíć S., Duputie A., Djurdjevíć V., Galíć Z., Stojníc S. 2013. Prediction of the European beech (Fagus sylvatica 
L.) xeric limit using a regional climate model: An example from southeast Europe. Agricultural and Forest Meteorology 176: 94-103. http://dx.doi. org/10.1016/j.agrformet.2013.03.009

Stokes M.A., Smiley T.L. 1968. An introduction to tree-ring dating. The University of Chicago Press.

Tegel W., Seim A., Hakelberg D., Hoffmann S., Panev M., Westphal T., Büntgen U. 2014. A recent growth increase of European beech (Fagus sylvatica L.) at its Mediterranean distribution limit contradicts drought stress. European Journal of Forest Research 133: 61-71. http://dx.doi.org/10.1007/ s10342-013-0737-7

Warren W.G. 1980. On removing the growth trend from dendrochronological data. Tree-Ring Bulletin 40: $35-44$. van der Werf G.W., Sass-Klaassen U.G.W., Mohren G.M.J. 2007. The impact of the 2003 summer drought on the intra-annual growth pattern of beech (Fagus sylvatica L.) and oak (Quercus robur L.) on a dry site in the Netherlands. Dendrochronologia 25: 103-112. http://dx.doi.org/10.1016/j. dendro.2007.03.004

Wigley T.M.L., Briffa K.R., Jones P.D. 1984. On the average value of correlated time series, with applications in dendroclimatology and hydrometeorology. Journal of Climate and Applied Meteorology 23: 201-213. http://dx.doi. org/10.1175/1520-0450(1984)023<0201:OTAVOC $>2.0 . \mathrm{CO} ; 2$ 